\title{
REVIEW
}

\section{Nitrogen fixing cyanobacteria: their diversity, ecology and utilisation with special reference to rice cultivation}

\author{
S.A. Kulasooriya* and D.N. Magana-Arachchi \\ National Institute of Fundamental Studies, Hantana Road, Kandy.
}

\begin{abstract}
Cyanobacteria are unique in their ability to conduct the two incompatible processes of $\mathrm{O}_{2}$ evolving photosynthesis and $\mathrm{O}_{2}$ sensitive $\mathrm{N}_{2}$ fixation within non-compartmentalised prokaryotic cells. Among the early life forms of the primitive Earth, cyanobacteria were the first to perform oxygenic photosynthesis. This process slowly changed the original reducing atmosphere of the Earth to an oxidising one, triggering off a dramatic evolution of global biodiversity. Under the original reducing atmosphere $\mathrm{N}_{2}$ fixation was widespread among the organisms that inhabited the Earth. As this atmosphere gradually became oxygenated, some including certain cyanobacteria developed mechanisms to protect their nitrogenase enzyme from damage by $\mathrm{O}_{2}$. Among the filamentous cyanobacteria a common adaptation is the formation of heterocysts, which are specialised for $\mathrm{N}_{2}$ fixation, but many unicellular species and some non-heterocystous filamentous forms have also developed mechanisms for aerobic $\mathrm{N}_{2}$ fixation. Recent findings have revealed the diversity and importance of novel diazotrophic unicellular cyanobacteria and their associations in the oligotrophic deep oceans. The discovery of the occurrence of unculturable marine diazotrophic cyanobacteria that possessed an unknown photo-fermentative metabolism, which was later found to be a symbiotic association is a case in point. Such findings indicate that there could be many new organisms and systems yet to be discovered and open up new vistas for future research. They also lend support to the novel hypothesis of symbiogenetic evolution. These reports have elevated the role of unicellular $\mathrm{N}_{2}$ fixing cyanobacteria and their symbiotic systems in the deep oceans.
\end{abstract}

The pioneering habitation of the early Earth by the ancestors of present day cyanobacteria is reflected in their ubiquitous global distribution from barren tropical deserts to freezing environments of glaziers. Together with certain Proteobacteria and Archaea they are common inhabitants of extreme environments that are generally inhospitable to most organisms. The role of $\mathrm{N}_{2}$ fixing cyanobacteria are exemplified by the significant contribution they make to the nitrogen budget of the oceans, which occupy more than $80 \%$ of the Earth's surface. Cyanobacteria are also found in freshwater and terrestrial habitats spanning across all latitudes and longitudes of the world and contribute significantly to the carbon and nitrogen cycles of wetlands, freshwater and brackish ecosystems as free-living, symbiotic, epiphytic, benthic and periphyton organisms. Certain $\mathrm{N}_{2}$ fixing cyanobacteria form blooms in lentic water bodies and some of them produce cyanotoxins. $\mathrm{N}_{2}$ fixing cyanobacteria therefore play both positive and negative roles in nature.

Cyanobacteria form symbiotic associations with all other major groups of organisms and contribute to the nutrition of their hosts. Certain cyanobacteria and their symbiotic systems like Azolla are used as biofertilizers, particularly in rice production.

This paper is a review of literature on $\mathrm{N}_{2}$ fixing cyanobacteria, their diversity, their roles in nature and their utilisation.

Keywords: Biofertilizers, cyanotoxins extremophiles, diazotrophic cyanobacteria, pioneer colonisers.

\section{NITROGEN FIXATION IN CYANOBACTERIA}

Biological nitrogen fixation (BNF) is the conversion of inert dinitrogen $\left(\mathrm{N}_{2}\right)$ into a combined form by living organisms through catalytic process of the enzyme nitrogenase. Among the vast myriad of diverse organisms present on the Earth, this process is confined to certain prokaryotic microorganisms. Nitrogen fixing prokaryotes could be autotrophic or heterotrophic, aerobic, micro-aerobic or anaerobic, and among them the cyanobacteria are the only prokaryotes that fix nitrogen and simultaneously carry out oxygen evolving 
photosynthesis. How the prokaryotic microorganisms which do not possess a compartmentalised cellular organisation with intracellular organelles carry out these two incompatible processes of oxygen sensitive nitrogen fixation and oxygen evolving photosynthesis, has drawn a variety of explanations but this engima is not yet completely resolved.

From phylogenetic studies it has been postulated that all the nitrogenases have been derived from a common prokaryotic ancestral group that existed prior to the oxygenation of the Earth's atmosphere (BermanFrank et al., 2003). This anoxic atmosphere was quite different from the present day atmosphere and had a predominance of $\mathrm{CH}_{4}, \mathrm{CO}_{2}, \mathrm{~N}_{2}$ and $\mathrm{NH}_{3}$. Ultra-violet radiation would have dissociated $\mathrm{NH}_{3}$ releasing $\mathrm{N}_{2}$ and $\mathrm{H}_{2}$ to the atmosphere. Primitive nitrogenases could have initially arisen as respiratory enzymes where $\mathrm{N}_{2}$ acted as a sink for anaerobic respiration of certain heterotrophs. The slow process of oxygenation over several millions of years, primarily due to the oxygenic photosynthesis of cyanobacteria, resulted in the partial pressure of atmospheric oxygen to increase from $0.0004 \%$ to $>0.03 \%$. This oxygenation was inimical to $\mathrm{N}_{2}$ fixation and all the organisms had to adopt various methods to protect their nitrogenase enzyme from damage by $\mathrm{O}_{2}$ (Gallon, 1981). Such evolutionary processes of adaptation would have been slow and gradual over a long period of time because the anaerobic atmosphere went through a long journey of micro-aerobic conditions to reach oxygen concentrations inimical to the nitrogenase enzyme. Gallon et al. (1991) and Gallon (1992) have described these mechanisms as behavioural adaptations, physical barriers, physiological and biochemical strategies and structural changes, and treated the cyanobacteria as a special group and these have been discussed by Kulasooriya (2008).

\section{DIVERSITY OF NITROGEN FIXING CYANOBACTERIA}

According to early reports, although $\mathrm{N}_{2}$ fixation was widespread among cyanobacteria, all species did not fix nitrogen. Many did so both under aerobic and micro-aerobic conditions while a lesser number fixed $\mathrm{N}_{2}$ only under aerobic conditions (Fogg et al., 1973). The information in this report has undergone major revisions during the past four decades particularly with respect to the number of unicellular species, which play a major role in nitrogen fixation in the deep open seas (Montoya et al., 2004; Moisander et al., 2010; Thompson \& Zehr, 2013).
During the $19^{\text {th }}$ century cyanobacteria (considered as blue-green algae at that time) were first suspected to fix atmospheric nitrogen due to their ability to grow well under nitrogen deficient conditions (Frank, 1889; Schloesing \& Laurent, 1892), but the observations were not based upon axenic cultures. Conclusive proof was provided by Drewes (1928) and this work was supported by De (1939), who showed that nitrogen fixing cyanobacteria were abundant in paddy fields of India. This showed the economic importance of these organisms as contributors for sustaining the natural fertility of rice soils (Singh, 1961).

Until the late 1950s and mid 1960s the difficulty of demonstrating $\mathrm{N}_{2}$ fixation in cyanobacteria was due to the limitation of reliable methods. The common methodology was based upon the demonstration of significant growth of the test organism under nitrogen free conditions. First it was necessary to ensure that the experimental cultures were axenic because it was tedious to remove the associated bacteria, which sometimes dwell within mucilage sheaths of the test organisms. Secondly it was necessary to establish unequivocally that the culture set up was completely free of combined nitrogen including those present as traces in the air bubbled through the cultures. The meticulous set up to remove such traces by Fogg (1942) was followed by many others until the acetylene reduction assay (Dilworth, 1966; Schollhorn \& Burris, 1966) became available. This simple technique enabled the rapid demonstration of nitrogenase activity by any organism, symbiotic association, cell-free extracts and purified nitrogenase enzyme under a variety of incubation conditions. However unequivocal confirmation of $\mathrm{N}_{2}$ fixation by any organism or system had to come from evidence supported by techniques using isotopes of nitrogen.

\section{Filamentous, heterocystous cyanobacteria}

During the early 1960 s there was no clear idea as to whether any specialised cell/s in filamentous cyanobacteria perform $\mathrm{N}_{2}$ fixation, and the role of heterocysts was not fully understood (Cox, 1966). The classical research article by Fay et al. (1968) brought a new dimension proposing that a specialised cell, the heterocyst is the site of $\mathrm{N}_{2}$ fixation in cyanobacteria. Accordingly the major adaptation for $\mathrm{N}_{2}$ fixation under aerobic conditions among the filamentous cyanobacteria appeared to be due to structural changes of their cells. A majority of filamentous cyanobacteria that exhibit aerobic nitrogen fixation possess heterocysts. Compared to vegetative cells heterocysts are generally larger in size, lighter in colour, have thicker cell walls and 
have thickenings called polar nodules at the points of attachment to adjacent cells (Fogg et al., 1973). Lang and Fay (1971) showed that a mature heterocyst has a thick envelope that consists of an outer polysaccharide fibrous layer, a middle homogenous layer and an inner glycolipid laminated layer. This cell envelope has been shown to be critically important for $\mathrm{N}_{2}$ fixation and also limits the ingress of $\mathrm{O}_{2}$ into the heterocysts (Murry et al., 1984; Murry \& Wolk, 1989). Kulasooriya et al. (1972) reported on the differentiation of heterocysts in Anabaena cylindrica and also demonstrated how it coincided with the restoration of nitrogenase activity. Isolated heterocysts of $A$. cylindrica showed higher rates of respiration than vegetative cells and their absorption spectrum coincided more closely with the action spectrum of nitrogenase activity by whole filaments than that of the vegetative cells (Fay \& Walsby, 1966). The isolated heterocysts contained very little chlorophyll-a and were devoid of phycocyanin and phycoerythrin pigments, which are associated with the $\mathrm{O}_{2}$ evolving photosystem-II of photosynthesis (Thomas, 1970). Using ${ }^{14} \mathrm{C}$ labelled $\mathrm{CO}_{2}$ Wolk (1970) showed that heterocysts do not fix carbon, and Fay and Kulasooriya (1972) demonstrated the prevalence of reducing conditions in heterocysts by the faster reduction of triphenyl tetrazolium chloride within them. Wolk and Wojciuch (1971) demonstrated photo-reduction of acetylene in isolated heterocysts. Employing the short-lived, radioactive isotope ${ }^{13} \mathrm{~N}$, Wolk et al. (1974) demonstrated $\mathrm{N}_{2}$ fixation within heterocysts and Janaki and Wolk (1982) showed the presence of nitrogenase in isolated heterocysts. Wolk (1982) reviewed and summarised all the available evidences and concluded that the main function of heterocysts in cyanobacteria is $\mathrm{N}_{2}$ fixation.

These early reports based primarily upon morphological and physiological characters have been confirmed later and a number of studies and many reviews have described the numerous phases in heterocyst development, signalling, and regulation (Meeks \& Elhai 2002; Forchhammer, 2004; Herrero et al., 2004; Zhang et al., 2006; Aldea et al., 2008; Zhao \& Wolk, 2008; Kumar et al., 2009). Heterocysts and vegetative cells are mutually interdependent. Heterocysts lack photosystem-II and carbon fixation. As such, they are dependent on vegetative cells for a source of carbon, which was probably partially supplied as sucrose (Cumino et al., 2007; Marcozzi et al., 2009) while vegetative cells obtain fixed nitrogen in the form of amino acids from the heterocysts (Meeks \& Elhai, 2002). In certain species, vegetative cells also supply glutamate to heterocysts, which convert it to glutamine and other amino acids (Martin-Figueroa et al., 2000). The exchange of metabolites and intercellular signals that control the regulated spacing of the heterocysts require movement of molecules between cells along a filament, possibly through a continuous periplasm (Flores et al., 2006). Mariscal et al. (2007) showed that the green fluorescent protein (GFP) expressed from the patS promoter, which is expressed at a low basal level in vegetative cells and strongly up-regulated in differentiating heterocysts and targeted to the periplasm by a cleavable twin-arginine signal peptide, could diffuse through the heterocyst periplasm to nearby vegetative cells. GFP attached to the cytoplasmic membrane was visible only in heterocysts and not in adjacent vegetative cells. However, according to Zhang et al. (2008), GFP targeted to the periplasm of vegetative cells or heterocysts showed no intercellular diffusion from one cell to the next and the exported GFP diffused around individual cells but not beyond the cell borders. The signal sequences they used were celltype specific promoters (P-hepA, P-patB or P-rbcL) and the signal sequence of the Escherichia coli TorA protein attached to GFP. It is unclear why these two research groups came to different conclusions. It may be because of the different signal sequences that were used (Kumar et al., 2009). It is therefore evident that although heterocysts in these cyanobacteria are the sites of nitrogen fixation, their continued functioning depends upon intimate connection and interaction with the vegetative cells.

\section{Non-heterocystous cyanobacteria}

\section{Unicellular cyanobacteria}

While evidence in support of heterocysts as the sites of $\mathrm{N}_{2}$ fixation was gaining momentum, reports appeared on the detection of nitrogenase activity in certain unicellular as well as non-heterocystous, filamentous species of cyanobacteria. The first report of a unicellular species being capable of nitrogen fixation was that of Wyatt and Silvey (1969) who demonstrated nitrogenase activity in Gloeocapsa (syn. Gloeothece, Cyanothece). These were followed by reports on other unicellular species such as Synechococcus and Aphanothece (Mitsui et al., 1986). In a survey of 133 species of non-heterocystous strains, Rippka et al. (1971) found nitrogenase activity in 46 strains and they also proposed the inclusion of all nitrogen fixing unicellular species into a single genus Cyanothece. It has been suggested that $\mathrm{N}_{2}$ fixation in Cyanothece takes place in the dark, supported by ATP and carbon substrates produced during the preceding light period and they are under a circadian rhythm (Huang \& Chow, 1991). However certain strains have been reported to grow fast under continuous light, and the formation of a certain type of intracellular granule was observed under these conditions. These granules were different from 
polybetahydroxy butarate (PHB) and cyanophycean granules, and were formed only under $\mathrm{N}_{2}$ fixing conditions in Cyanothece (Reddy et al., 1993). The dissolved $\mathrm{O}_{2}$ levels under which unicellular species fix $\mathrm{N}_{2}$ have been found to be within a range of 27 to $80 \mu$ moles, much lower than $300 \mu$ moles tolerated by heterocystous cyanobacteria. The inhibition of nitrogenase activity in Gloeotheca by giving a high level $\mathrm{O}_{2}$ shock recovered 1 to 2 hours after the shock was removed. However, this recovery did not occur if an inhibitor of protein synthesis like chloramphenicol was added. This was interpreted as continuous synthesis of nitrogenase as a strategy to overcome the inhibition of $\mathrm{N}_{2}$ fixation in Gloeotheca (Gallon \& Hamadi, 1984). Two Synechococcus ecotypes inhabiting the Octopus Spring microbial mat of the Yellowstone National Park was shown to fix $\mathrm{N}_{2}$ within a temperature range of 53.5 to $63.4{ }^{\circ} \mathrm{C}$ towards the evening supported by energy generated during photosynthesis in the forenoon (Steunou et al., 2006). This is the first report of a thermophilic unicellular cyanobacterium fixing $\mathrm{N}_{2}$.

Although several unicellular species of cyanobacteria have been reported to be capable of $\mathrm{N}_{2}$ fixation both under free-living and symbiotic associations (Wyatt \& Silvey, 1969; Mitsui et al., 1986; Ortega-Calvo \& Stal, 1991), their contribution to the global nitrogen cycle was not considered as significant as those of heterocystous filamentous and non-heterocystous filamentous cyanobacteria such as species of Trichodesmium. During the last few years however this view has changed with several reports showing not only the widespread distribution of diazotrophic unicellular cyanobacteria in the oligotrophic oceans, but also the diverse mechanisms they have adopted to fix nitrogen at high rates particularly in the marine ecosystems (Montoya et al., 2004; Needoba et al., 2007; Moal \& Biegala, 2009; Moisander et al., 2010; Bandyopadhyay et al., 2012; Thompson \& Zehr, 2013). Significant differences in the patterns of respiration and nitrogen fixation among different strains of Cyanothece were demonstrated by Bandyopadhyay et al. (2012), where the strain 51142 showed the highest rate of aerobic $\mathrm{N}_{2}$ fixation and an exceptionally high rate of hydrogen evolution. $\mathrm{H}_{2}$ plays multiple roles in $\mathrm{N}_{2}$ fixation and in this case it appears to have acted as an electron acceptor in competition with $\mathrm{N}_{2}$.

Tripp et al. (2010) have reported on a globally distributed, periodically abundant $\mathrm{N}_{2}$-fixing marine, yet uncultivated, unnamed cyanobacterium UCYN-A, which was found to lack the oxygen-producing photosystem-II complex of the photosynthetic apparatus, indicating a novel metabolism. From metabolic reconstructions it was inferred that UCYN-A has a photofermentative metabolism and is dependent on other organisms for essential compounds. However, size fractionation experiments using natural populations did not provide evidence of a symbiotic association with another microorganism. It has been concluded that UCYN-A cyanobacterium is a paradox in evolution and adaptation to the marine environment and is an example of the tight metabolic coupling between microorganisms in oligotrophic oceanic microbial communities (Tripp et al., 2010). This type of relationships have been cited as likely sources of undiscovered symbioses (Adams et al., 2012). This prediction came true when subsequent reports contributed to the elucidation of this enigmatic relationship (Thompson et al., 2012; Thompson \& Zehr, 2013). UCYN-A was shown to have a symbiotic relationship with a eukaryotic, unicellular prymnesiophyte (Thompson et al., 2012). Such cellular interactions of nitrogen fixing cyanobacteria in the oligotrophic deep oceans may even be reflecting similar relationships that have resulted in the evolution of chloroplasts in the primitive Earth in which cyanobacteria and other prokaryotes were predominant (Kulasooriya, 2011). These ideas have been strongly supported by Carrapiço (2015) who has proposed symbiogenesis (symbiont induced speciation), which plays an important role as an evolutive mechanism with the acquisition of new genomes and new metabolic capabilities (Shapiro, 2012).

\section{Filamentous non-heterocystous cyanobacteria}

One of the earliest demonstrations of a non-heterocystous filamentous cyanobacterium exhibiting nitrogenase activity was that of Plectonema boryanum under micro-aerobic conditions (Stewart \& Lex, 1970). This was followed by similar demonstrations for species of Oscillatoria, Lyngbya and Plectonema (Kenyon et al., 1972). Subsequent reports showed that certain filamentous non-heterocystous forms like Microcoleus chthnoplastes (Pearson et al., 1981), a marine Lyngbya sp. (Jones, 1990) and Oscillatoria sp. (Gallon et al., 1991) do so even under aerobic conditions. In all these cases it has been found that there was a temporal separation of the two incompatible processes of oxygenic photosynthesis and oxygen sensitive $\mathrm{N}_{2}$ fixation along the growth cycle of these organisms.

The most enigmatic situation with non-heterocystous, filamentous cyanobacteria was encountered with Trichodesmium erythraenum, which was reported to be associated with high rates of aerobic $\mathrm{N}_{2}$ fixation in marine ecosystems (Dudgale et al., 1964) and demonstrated to fix nitrogen originally by Ramamoorthy and 
Krishnamoorthy (1968). As this initial report was based primarily on the ability of this cyanobacterium to grow well through several transfers in $\mathrm{N}$-free culture media, it was not widely accepted until more direct evidence became available. Subsequent evidences based upon the demonstration of nitrogenase activity by the acetylene reduction assay as well as ${ }^{15} \mathrm{~N}_{2}$ fixation confirmed that $T$. erythraenum is a very efficient nitrogen fixing species. Large marine blooms of $T$. erythraenum have been reported to show very high nitrogenase activity and it was the main contributor to the nitrogen budget of the deep oceans (Karl et al., 1997). Two other species, T. theibautii and T. aureum have also been identified as nitrogen fixing, non-heterocystous, filamentous, aerobic marine cyanobacteria. Certain studies have demonstrated a diurnal variation and the presence of some specialised cells called diazocytes in these organisms and it has been suggested that the nitrogenase enzyme is confined to these cells (Jansen et al., 1994; Fredrickson \& Bergman, 1995; 1997; Lin et al., 1998; Mulholland \& Capone, 2000). Nitrogen fixation in Trichodesmium peaked around mid-day and varied inversely with photosynthetic $\mathrm{O}_{2}$ evolution. It has also been suggested that $\mathrm{N}_{2}$ fixation and photosynthesis in Trichodesmium is regulated by circadian rhythms (Chen et al., 1998). Molecular studies have shown that nitrogenase is synthesised early morning and nifH mRNA is highest before dawn (Wyman et al., 1996). This enzyme remained active until noon when it reached a peak, then declined in the afternoon and got degraded during the night (Capone et al., 1990; Zehr et al., 1993). Twelve nif genes cloned and sequenced from Trichodesmium are basically similar to those of other cyanobacteria, but show a closer resemblance to 'vegetative cell nitrogenase genes' induced in Anabaena variabilis under micro-aerobic conditions. In a later review Sandh et al. (2012) have reconfirmed the presence of diazocytes in the filaments of marine Trichodesmium. Detailed examination of the development of this specific cell type (so far not discovered in any other cyanobacterium) revealed structural (light microscopy and electron microscopy), physiological and molecular characteristics unique to them. However, the presence of diazocytes has been questioned by Finzi-Hart et al. (2009), who applied a highly sensitive nanometer scale secondary ion mass spectrometry (NanoSIMS) technique to trace the fate of $\mathrm{C}$ and $\mathrm{N}$ assimilation in Trichodesmium. Using the isotopes ${ }^{13} \mathrm{C}$ and ${ }^{15} \mathrm{~N}$ combined with transmission electron microscopy (TEM) of thin sections, they characterised the uptake patterns in individual cells of Trichodesmium filaments and showed transient incorporation of $\mathrm{C}$ and $\mathrm{N}$ into discrete cyanophycean granules within individual cells. They speculate that these granules act as dynamic storage bodies to uncouple $\mathrm{CO}_{2}$ and $\mathrm{N}_{2}$ fixation from overall growth dynamics. Confirming earlier reports they observed maximum $\mathrm{CO}_{2}$ fixation in the morning followed by maximum $\mathrm{N}_{2}$ fixation in the afternoon supporting the hypothesis of a temporal segregation of the two incompatible processes. They concluded that unraveling the exact mechanisms and physiological complexities of this globally important cyanobacterium still remains a challenge for future research.

Many other non-heterocystous cyanobacteria such as species of Oscillatoria, Lyngbya, Microcoleus and Plectonema boryanum have been induced to fix nitrogen under micro-aerobic conditions. Among other strategies, aggregation of unicellular and non-heterocystous cyanobacteria to form algal mats, colonies and biofilms among themselves and with other microorganisms have been reported to exhibit nitrogenase activity in marine Synechococcus and terrestrial and freshwater Oscillatoria, Lyngbya, Microcoleus and Plectonema. Physical barriers such as thick mucilaginous sheaths and capsules have enabled aerobic nitrogen fixation in Gloeotheca (syn. Goeocapsa, Cyanotheca).

In their recent review Issa et al. (2014) cover most of the literature published up to the late 1980s to explain how the two incompatible processes of nitrogen fixation and oxygenic photosynthesis exist in unicellular as well as undifferentiated filamentous cyanobacteria. The mechanisms they cite range from $\mathrm{N}_{2}$ fixation being confined to dark phases of growth, following a cyclic pattern under continuous light, higher respiration creating micro-aerobic conditions in certain cells and phycobiliprotein regulated $\mathrm{O}_{2}$ evolution, to a possible switching off mechanism of photosynthesis in Oscillatoria. They have treated Trichodesmium as a special case and cited the early work of Fredriksson and Bergmen (1997) on the presence of specialised cells capable of $\mathrm{N}_{2}$ fixation. They even question the affiliation of this genus in the cyanobacteria.

As nitrogen fixation is believed to have been widespread among the prokaryotic organisms (including cyanobacteria) during the archaic anoxic periods of the Earth (Berman-Frank et al., 2003), it is not surprising to find such abilities among the genomes of most of the present day cyanobacteria, which could resume their functions when micro-aerobic conditions are prevalent or induced.

All these evidences support the idea that although heterocysts are specialised cells for $\mathrm{N}_{2}$ fixation in filamentous cyanobacteria the potential to fix $\mathrm{N}_{2}$ is present 
even in the vegetative cells, but this is normally expressed only under reduced oxygen concentrations. These observations have important ecological implications and it is quite likely that the subterranean layers of thick mats of non-heterocystous cyanobacteria may be fixing nitrogen particularly under low light conditions or in the dark. This idea is also compatible with the evolution of the process of $\mathrm{N}_{2}$ fixation from an archaic reducing Earth's atmosphere through a micro-aerobic atmosphere to the oxygenated atmosphere of present times (Gallon et al., 1991; Berman-Frank et al., 2003).

\section{Ecosystem diversity}

Nitrogen fixing cyanobacteria are ubiquitous in their global distribution and occupy a broad range of habitats across all latitudes and longitudes perhaps indicating their pioneering ancestry in the primitive Earth. They are widespread in freshwater and terrestrial habitats, but not so common in marine ecosystems except in certain oligotrophic deep ocean areas. They are frequent inhabitants of extreme habitats such as freezing conditions of the glaziers in the Arctic and Antarctic regions, hot spring micro-flora and epilithic and endolithic species found as the only inhabitants of the arid Atacama Desert. Many lichens with cynobacterial endosymbionts demonstrate their ability to colonise habitats that are inhospitable to other organisms.

\section{Terrestrial ecosystems}

Cyanobacteria have been observed as common pioneering species in the colonisation of bare rocks (as lichens), exposed habitats devastated by natural disasters like volcanic eruptions, landslides, tornadoes, tsunamis and hurricanes as well as man made barren lands due to mining and land clearance for constructions. They are also common inhabitants of concrete walls, metal surfaces and insulations of high tension power lines, blades and towers of wind mills and such nutrient deficient substrates wherever there is light and moisture. Such colonisation capabilities of cyanobacteria could be attributed to their ability of both carbon and nitrogen fixation. It could also be a reflection of their long ancestry originating from the primitive Earth, which was inhospitable to most life forms. These features that certain cyanobacteria show in common with other extremophilic microorganisms such as exposure to high light, tolerance to UV radiation, desiccation, the ability to withstand very high to freezing temperatures and tolerance to acidity and alkalinity make them ideal candidates for Astrobiological studies (Seckbach, 2006; Francis et al., 2010; Billi et al., 2013) and in the search for novel bioactive compounds for the drug industry (Aleksandra et al., 2007). A survey of hot spring cyanobacteria in Sri Lanka has reported on the presence of Gleocapsa sp., Synechococcus, Xenococcus, Chroococcus, Phormidium sp., Leptolyngbya sp., Oscillatoria sp., Phormidium, Calothrix and Chlorogloeopsis sp. (Wanigatunge, 2014). From the foregoing it is evident that unicellular cyanobacteria are common among the extremophiles specially under higher temperatures. The contribution of $\mathrm{N}_{2}$ fixation by cyanobacteria to these ecosystems is yet to be established.

The colonisation abilities of inhospitable habitats by cyanobacteria have been sometimes utilised as in the case of the reclamation of alkaline 'Usar soils' of India by the application of Aulosira fertilisima as a biofertilizer (Singh, 1961). Cyanobacteria are common on the barks of forest trees and other moist habitats often in association with bryophytes, mosses and ferns. They are also frequent inhabitants of drains carrying sewage and polluted water including factory effluents, banks of canals, ponds and reservoirs, and as periphyton flora of slow moving streams and rivers.

\section{Freshwater and wetland ecosystems}

Cyanobacteria are common inhabitants among the phytoplankton of lentic water bodies such as ponds, irrigation tanks, reservoirs, lakes and wetlands like rice paddies. Very often certain cyanobacteria become dominant when freshwater ecosystems get polluted and sometimes they are even used as bio-indicators of pollution. Kulasooriya (2005) reported on the changes of cyanobacterial diversity in inland freshwater bodies of Sri Lanka during the $20^{\text {th }}$ century primarily due to pollution by anthropogenic activities. With the increase of pollution the overall diversity of phytoplankton diminishes and a few cyanobactrial species particularly toxigenic ones become predominant suppressing the more sensitive species. In eutrophic waters such cyanobacteria form 'algal blooms' and a number of them are toxigenic. Limnologists often attribute algal bloom formation to pollutants particularly those containing phosphorus and nitrogen. A number of toxigenic, bloom forming members such as Anabaena, Cylindrospermopsis, Nodularia and Aphanizomenon are $\mathrm{N}_{2}$ fixing genera and they have the advantage of rapid growth in phosphorus rich waters even under N-limiting conditions. However, a common bloom forming toxigenic genus Microcystis is a non-fixing, unicellular colonial form.

In wetland rice fields $\mathrm{N}_{2}$ fixing cyanobacteria have been observed as epiphytes on rice field weeds 
(Kulasooriya et al., 1981a) and on rice plants (Roger et al., 1981). Occasionally they have been reported even as endophytic organisms in deepwater rice (Kulasooriya et al., 1981b) providing fixed nitrogen to the host plants (Watanabe et al., 1981). The common occurrence of cyanobacteria in wetland rice field ecosystems has been utilised in rice production in certain countries by the application of selected nitrogen fixing genera as biofertiliser inoculants (Venkataraman, 1972; Roger \& Kulasooriya, 1980). In a study on the relationship between the abundance of $\mathrm{N}_{2}$ fixing cyanobacteria and environmental features in Spanish rice fields, Quesada and Fernandez-Valiente (1996) investigated 25 sampling sites in rice fields in Valencia, three times a year for two years. Correlation analysis with environmental features showed that cyanobacterial abundance was influenced more by water than soil properties. Salinity, mineralisation variables and soluble reactive phosphate (SRP) correlated positively with the presence of heterocystous cyanobacteria. Dissolved inorganic nitrogen (DIN) and the ratio DIN:SRP correlated negatively with cyanobacterial abundance.

Cyanobacteria are seldom found in the phytoplankton of fast flowing rivers and streams. In slow moving waters and streams they are more frequent as the benthic flora as well as attached to stream substrates as the periphyton (Maracarelli et al., 2008; Stancheva et al., 2013). Marcarelli et al. (2008) in their review report states that in streams the dominant autotrophic $\mathrm{N}_{2}$ fixers are heterocystous cyanobacteria such as Nostoc, Anabaena and Calothrix and that no researcher has confirmed the presence of unicellular free-living $\mathrm{N}_{2}$ fixing members except those in endosymbiosis with diatoms such as Rhophalodia and Epithemia. They also record that $\mathrm{N}_{2}$ fixing cyanobacteria rarely contributes more than $5 \%$ to the $\mathrm{N}$ budget of in-stream ecosystems and this was significantly lower than denitrification and dissolved inorganic nitrogen uptake rates. However they conclude that studies on in-stream $\mathrm{N}_{2}$ fixation are limited and have the drawback of not recording all the inputs and outputs of this ecosystem simultaneously. Stancheva et al. (2013) have confirmed the dominance of heterocystous freeliving cyanobacteria among the phototrophic $\mathrm{N}_{2}$ fixers in the stream micro-flora, together with the diatoms Epithemia and Rhopalodia with their endosymbiotic cynobacteria. Recording data from a total of 104 stream sites across 29 watersheds in southern California, they report threshold concentrations of low inorganic $\mathrm{N}$ and low N:P ratios and high $\mathrm{N}_{2}$ fixation by cyanobacteria. They suggest that changes of these organisms can be used for the bio-assessment of nutrient content of stream ecosystems.

\section{Marine ecosystems}

The primary production in vast areas of the deep oceans is determined largely by the availability of carbon and nitrogen. In these environments biological fixation of carbon and nitrogen plays a critical role to overcome $\mathrm{N}$ limitation. Blooms of marine nitrogen fixing Trichodesmium erythraeum in the tropical oligotrophic deep oceans are reported to contribute significantly to their nutrient status through carbon and nitrogen fixation. They play a vital role in the sustenance of these ocean ecosystems by acting as primary producers (Nadis, 2003). Staal et al. (2003) have provided a plausible explanation based upon temperature as to why nitrogen fixation is limited to the non-heterocystous Trichodesmium in the tropical and subtropical pelagic environments, whereas species having heterocysts dominate nitrogen fixation in freshwater lakes and brackish environments like the Baltic Sea.

Similarly Brauer et al. (2013) have explained the possible causes for the restriction of the unicellular, marine, diazotrophic, cyanobacterium Cyanothece within tropical and sub-tropical oceans. They reported that low temperature delays the timing and enhances nitrogen fixation in Cyanothece while specific growth rate increased strongly with temperature from 18 to $30^{\circ} \mathrm{C}$ beyond which it levelled off. Several recent reports have suggested a significant change on the role and importance of $\mathrm{N}_{2}$ fixation by unicellular cyanobacteria and their symbiotic and other associations to the marine ecosystems (Tripp et al., 2010; Foster et al., 2011; Bandyopadhyay et al., 2012; Thompson et al., 2012; Thompson \& Zehr, 2013). Accordingly $\mathrm{N}_{2}$ fixation by unicellular cyanobacteria can be considered as vital for these ecosystems and Cyanothece and its symbionts could sometimes be considered as keystone species.

The red pigmented Trichodesmium commonly occurs in the tropical oceans where the temperatures are around $25{ }^{\circ} \mathrm{C}$ and salinity close to $3.5 \%$. It is believed by some that the Red Sea got its name due to periodic red blooms and red tides caused by Trichodesmium (Fogg et al., 1973). In the deep oceans these blooms sometimes extend to several miles, and Wood (1965) has reported on a massive bloom of $52,000 \mathrm{~km}^{2}$. Carpenter and Romans (1991) claim Trichodesmium as the most important primary producer in the North Atlantic Ocean. It makes net assimilation rates of carbon (ca $165 \mathrm{mgC} / \mathrm{m}^{2} /$ day) and the highest fraction of new nitrogen (ca $30 \mathrm{mgN} / \mathrm{m}^{2}$ / day) to the euphotic zone. Karl et al. (1997) presenting seven years of time series observations in sub tropical gyre of the North Pacific Ocean claims that $\mathrm{N}_{2}$ fixation by cyanobacteria accounted for half of the new nitrogen produced in this ecosystem. 


\section{ASSOCIATIONS WITH OTHER ORGANISMS}

A diversity of extracellular and intracellular symbiotic interactions occur between $\mathrm{N}_{2}$ fixing cyanobacteria, bacteria and eukaryote hosts. In an extensive review Adams et al. (2012) have provided comprehensive information on the wide diversity, physiology, biochemistry, ecology, genetics and evolutionary tendencies among the symbiotic relationships of cyanobacteria with a variety of eukaryotes, protists, animals and plants. This book chapter, well illustrated with a number of elegant photographs, also includes current research interests and attempts on inducing such associations for potential applications. The degree of interconnection between partners ranges from weak dependence of some extracellular, epiphytic and endophytic associations to permanent or obligate intracellular symbiosis and in the latter case, the endosymbiont is transmitted vertically to the next generation without any need for re-infection (Kneip et al., 2008; Adams et al., 2012). Cyanobacterial interactions with plants and protists are also well known and in most cases the associations are facultative, without any vertical transmission (Kneip et al., 2008). The pennate diatom Rhopalodia gibba harbours endosymbionts closely related to extant cyanobacteria. Some of the closest free-living relatives of these so-called spheroid bodies are diazotrophic cyanobacteria of the Cyanothece sp. group (Prechtl et al., 2004; Bothe et al., 2010a). The spheroid bodies encode genes for nitrogen fixation and have the capacity to fix molecular nitrogen. In contrast to many other unicellular nitrogen fixing cyanobacteria, these organisms fix nitrogen only under light conditions. Here the symbiont (spheroid body) can fix nitrogen for its eukaryotic host, and the findings of Kneip et al. (2008) provide insight into the genome evolution of a nitrogen-fixing endosymbiontic cyanobacterium living within a unicellular eukaryotic host. The spheroid body of Rhopalodia gibba provides an opportunity to investigate the changes in endosymbiont physiology and genome evolution during adaptation of a symbiont to an intracellular environment. A recent report by Foster et al. (2011) using high resolution nanometer scale secondary ion mass spectrometry presented cell specific rates of $\mathrm{N}_{2}$ fixation in the marine diatom RicheliaCalothrix symbiosis. The rates of symbiotic $\mathrm{N}_{2}$ fixation were $171-420$ times higher than that of the free living organism. They also demonstrated that $97.3 \%$ of the fixed nitrogen was transferred to the host diatom. This novel information on the control of $\mathrm{N}$ input in the deep open sea provides a new dimension to the primary production in these ecosystems. These relationships also provide supportive evidence to the hypothesis of Carrapiço (2015) on symbiogenesis initiating evolutive speciation and this could be happening even today in the oligotrophic deep oceans with their harsh environments being similar to some extent to the conditions of the primitive Earth.

Diatoms such as Chaetoceros and Rhizosolenia possess symbiotically associated cyanobacteria. They are also found in association with marine coralline algae and limestones e.g. Scytonema endolithicum in Hyella stella.

In terrestrial ecosystems, cyanobacteria show endosymbiontic relationships with all other major groups of plants. With fungi they form lichens. Bryophytes Anthoceros and Blasia contain heterocystous cyanobacteria as endo-symbionts. The pteridophyte Azolla contains Ananbaena azollae within the cavities of the upper lobes of its bifurcated leaves. The negatively geotropic coralloid roots of Cycads (gymnosperms) possess intra-cellular Anabaena cycadaerium in their cortical cells and the nodules at the base of the petioles of the angiosperm Gunnera bear a species of Nostoc as an endo-symbiont.

In such symbiotic associations the cyanobacterial partner supplies nitrogen to the host through $\mathrm{N}_{2}$ fixation and the host provides a micro-niche and nutrients for the endo-symbiont. Just like in the Richelia-Calothrix symbiosis, the rates of fixation by these systems are higher than those of free-living cyanobacteria, perhaps due to the additional nutrition and micro-aerobic conditions provided by the host plant.

These associations with a wide range of diverse hosts representing all the major groups of the terrestrial flora, could also be a reflection of cyanobacteria being a predominant group among the early inhabitants of the primitive Earth. As new groups of higher plants evolved among a preponderance of cyanobacteria the chances of establishing such associations is a most likely possibility.

\section{BIOCHEMISTRY AND GENETIC REGULATION OF $\mathrm{N}_{2}$ FIXING CYANOBACTERIA}

The basic enzyme complex nitrogenase that catalyses $\mathrm{N}_{2}$ fixation is common to all $\mathrm{N}_{2}$ fixing organisms. Information available up to 2006 on the biochemistry including the structure of the nitrogenase enzyme complex, the proposed mechanism of nitrogen reduction and its genetic regulation has been reviewed by Kulasooriya (2008). The nitrogenase complex is composed of two components: a Fe-protein or component II, which is a dimer having a molecular weight ranging from 62,000 to 64,000 daltons 
and a Mo-Fe-protein or component I, a tetramer having a molecular weight ranging from 220,000 to 230,000 daltons. The latter also possess the Fe-Mo-co-factor, which has no peptide residues and has inorganic constituents with an approximate stoichiometry of $\mathrm{Fe}_{6} \mathrm{Mo}_{4} \mathrm{~S}_{4}$. The $\mathrm{N}_{2}$ molecule gets attached to the site of the co-factor and undergoes stepwise reduction through the enzyme bound intermediates $\mathrm{N}_{2} \mathrm{H}_{2}$ and $\mathrm{N}_{2} \mathrm{H}_{4}$ to finally produce the enzyme free key intermediate $\mathrm{NH}_{3}$. This enzyme free end product $\mathrm{NH}_{3}$ is released in cell free extracts and in vitro demonstrations using purified nitrogenase, but immediately incorporated in the intact organisms into the amino acid glutamine by the glutamine synthetase and L-glutamine 2-oxo glutarate 2-amino transferase (glutamate synthase) (GS/GOGAT) pathway. These basic biochemical mechanisms of nitrogen fixation were extensively studied and initially demonstrated in the anaerobic bacterium Clostridium pasteurianum and the facultative anaerobe Klebsiella pneumonia, but have been found to be similar in all $\mathrm{N}_{2}$ fixing organisms including the cyanobacteria. Among cyanobacteria the common experimental species studied have been Anabaena variabilis and Anabaena (Nostoc) PC 7220. A generalised scheme has been accepted for all $\mathrm{N}_{2}$ fixing microorganisms with minute variations between the major groups such as the proteobacteria and the cyanobacteria. Besides the 2-component nitrogenase complex, other anciliary reactions are needed for the complete $\mathrm{N}_{2}$ fixation process. It requires $\mathrm{Mg}^{2+}$ ions to activate the ATP and accept electrons (reducing power) transported by electron carriers ferredoxins and flavodoxins. This MgATP complex binds to the Fe-protein, which makes it highly reductive and energised. This complex then binds to the Fe-Mo-co centre of the Mo-Fe-protein and makes this site highly energised and reductive. Energy and reducing power (electrons) are accepted by the Mo-Fe-protein only from the reduced and energised Fe-protein and no other source. The energised and highly reduced Fe-Mo-co centre is now capable of reducing triple bonded substrates such as $\mathrm{N}_{2}, \mathrm{C}_{2} \mathrm{H}_{2}, \mathrm{CN}$, iso- $\mathrm{CN}$, azides etc. Accordingly the Feprotein component is termed dinitrogenase reductase and the Mo-Fe-protein component as dinitrogenase to reflect their major functions in the overall enzymatic process.

Besides the Mo-Fe protein of the nitrogenase complex, it has been revealed that there are two other complexes: Vanadium-Iron (V-Fe protein) and Iron-Iron (Fe-Fe protein) formed in most $\mathrm{N}_{2}$ fixing organisms including the cyanobacteria, specially under Mo deficient conditions.

In an extensive review article Bothe et al. (2010b) have reported more recent information on the mechanisms of $\mathrm{N}_{2}$ fixation and $\mathrm{H}_{2}$ metabolism in cyanobacteria including their genetic regulation. According to this article the pattern of pyruvate degradation, ammonium and $\mathrm{H}_{2}$ formation by nitrogenase, and $\mathrm{H}_{2}$ uptake by hydrogenases is not only typical of strict and facultative anaerobic bacteria, but also proceeds in cyanobacteria. It has been reported that a transitional 2:1 state is formed between the two nitrogenase components with the larger Mo-Fe component in the centre and one molecule of the smaller component (Fe-protein) attached at each end. It is the prosthetic group (4Fe-4S) cluster that bridges the sub-unit interface and is ligated by 2 cysteinyl residues from each sub-unit. This cluster accepts reducing equivalents from the electron carriers and also binds MgATP/MgADP. The overall reaction of the reduction of one molecule of nitrogen to produce two molecules of ammonia can be depicted by the following equation from Bothe et al. (2010b).

$$
\begin{aligned}
& 8 \mathrm{H}^{+}+8 e^{-}+ \mathrm{N}_{2}+16 \mathrm{MgATP} \rightarrow \\
& 2 \mathrm{NH}_{3}+\mathrm{H}_{2}+16 \mathrm{MgADP}+16 \mathrm{P}_{\mathrm{i}}
\end{aligned}
$$

\section{GENETIC REGULATION}

In addition to the three structural genes nifHDK, nitrogenase expression requires a total of 20 genes in the enterobacterium Klebsiella pneumonia and all of them are contiguously located on the chromosome. Before nitrogenase can be expressed in cyanobacteria a gene rearrangement has to occur within the nifD (Bothe et al., 2010b). A 11-kb DNA element is excised by a specific enzyme XisA and the two fractions of nifD are ligated to permit nitrogenase transcript formation. The excisase gene xisA is located on the excised DNA element. This gene re-arrangement occurs in heterocystous cyanobacteria such as Anabaena variabilis and Anabaena (Nostoc) PC7120, but not in non-heterocystous $\mathrm{N}_{2}$ fixing forms. Similar re-arrangements have also been reported in the late stages of heterocyst development of certain other cyanobacteria. In a more recent publication Pratte and Thiel (2014) have provided more evidence on the regulation of nitrogenase gene expression by transcript stability in the cyanobacterium Anabaena variabilis. They propose that the regulation of nitrogenase expression in cyanobacteria is different from that in the proteobacteria. An active nitrogenase requires the products of many genes and several of them are needed for the synthesis and insertion of the Fe-Mo-cofactor. In cyanobacteria they include a single cluster of nifB, $f d x N$, nifS, nifU, nifH, nifD, nifK, nifE, nif $N$, nif $X$ and nifW as well as hes $A B$, $f d x H$ and four open reading frames within the cluster. They also re-state the removal of the $11-\mathrm{kb}$ excision factor (Bothe et al., 2010b) towards the later stages of heterocyst development. Pratt and Thiel (2014) refer 
to earlier reports of the nif cluster in Anabaena having several operons with transcription start sites identified upstream of $n i f B$ and $n i f H$. However, these authors were unable to drive a transcription of lacZ using a DNA fragment that included the entire nifU1 - nifH1 intergenic region of A.variabilis. They showed that the 5' end of the nifH1 transcript is a processed transcript rather than a transcription initiation site, and there is no promoter upstream of nifH1. In contrast nifB 1 has a promoter that initiates transcription and there is a promoter within the coding region of nifUl, which has been verified by transcriptome sequencing (RNA sequencing). They show that the nifl cluster in A. variabilis from nifB1 through nifWl depends primarily on the nifB 1 promoter together with contributions from weak promoters in the nifU1 and nifE1 regions.

Cyanobacteria do not synthesise nitrogenase when grown in the presence of nitrate or ammonium, and the genetic regulation of nitrogen metabolism in cyanobacteria is different. According to recent findings, expression of nitrogen assimilation genes het $R$ involved in heterocyst differentiation and $g \ln A$ involved in ammonia assimilation, are regulated by the NtcA transcriptional regulator. The analysis of nifH sequences is widely used as a measure for the potential of a system to fix dinitrogen and for the diversity of diazotrophic organisms in that ecosystem. Until recently Microcoleus chthonoplastes has not been assigned as a diazotrophic organism and none of the strains that were correctly identified as M. chthonoplastes has been shown to fix dinitrogen. It has repeatedly been reported that these organisms lacked the cyanobacterial nifH, the structural gene for dinitrogenase reductase. However the study by Bolhuis et al. (2010) has shown the presence of the complete nif-gene cluster in the genome of $M$. chthonoplastes PCC 7420 and that the three structural nitrogenase genes nifHDK, are present in a collection of axenic strains of M. chthonoplastes from distant locations. Researchers have identified the areas in which future studies needs to be concentrated on, such as studying the transcriptional regulators, genes, and signalling pathways i.e. the genetics, their physiology, biochemistry and ecology not only in heterocyst formers, but also in non-heterocystous and in symbiotic cyanobacteria.

According to some researchers, one of the largest obstacles in determining the overall importance of symbiotic associations to the global cycling of nitrogen is the lack of consistent rate measurements. Certain studies have combined ${ }^{15} \mathrm{~N}$ isotope rate measurements with quantitative PCR approaches, which is a promising path forward. Although molecular and microscopic characterisation of nitrogen symbioses has helped to elucidate the diversity and distribution of symbioses, future work should target a consistent approach to relate these to their biogeochemical importance. Another difficulty faced by scientists today is that although it is possible to see the expressions under natural conditions, they have been unable to express these functions in laboratory strains.

\section{UTILISATION OF NITROGEN FIXING CYANOBACTERIA}

Free living nitrogen fixing cyanobacteria and the aquatic fern Azolla (which has nitrogen fixing Anabaena azollae as an endosymbiont) have been used as biofertilizers in rice cultivation.

Venkataraman (1972) provides a comprehensive account of the large scale production of cyanobacterial biofertilisers in India and their use in rice cultivation. Cyanobacteia are initially isolated from rice fields, purified and screened for rapid growth and high $\mathrm{N}_{2}$ fixation. Selected isolates are then semi-mass cultured in laboratory media and these are used as inoculants for soil based outdoor mass cultures in open ponds or large trays under non-sterile conditions. A sprinkle of $\mathrm{P}$ fertilizer, lime and pesticides are usually added to ensure uninhibited rapid growth. After sufficient growth is obtained the cultures are allowed to sun dry and the soil based algal flakes are packed and distributed among farmers to be used as biofertiliser inoculants. This low cost technology quite suitable for resource poor rural farmers has been successful only in a few areas in India, where edaphic conditions are favourable for the growth of cyanobacteria. Reports from certain areas of Myanmar, China and Egypt have also recorded some successes. Roger and Kulasooriya (1980) reviewed most of the literature on the use of cyanobacterial biofertilisers and concluded that the reported $\mathrm{N}$ input potential ranged from 0 to $80 \mathrm{~kg} / \mathrm{ha} / \mathrm{season}$ with an average of $25 \mathrm{~kg} / \mathrm{ha}$. Subsequently Roger et al. (1987) compared the population densities of nitrogen fixing cyanobacteria indigenously present in rice soils from India, Malaysia, The Philippines and Portugal with those of soil based inoculants used in rice cultivation. Nostoc sp. was predominant in these communities followed by Anabaena and Calothrix. The population densities (expressed as colony forming units per square centimeter) were not very different between indigenous soils and soil based inoculants. Based on these findings it was suggested that more attention should be given to agricultural practices that enhance the growth of indigenous strains rather than the introduction of artificial populations through inoculation. Mishra and Pabbi (2004) reported on improvements and refinements 
to soil based cyanobacterial biofertiliser production technologies described by Venkataraman (1972). These included enclosed semi-mass production instead of open air cultivation to minimise contamination, small pond cultivation of single species cultures, and embedding them in carrier material in order to reduce the inoculant load per hectare of rice fields. Despite these modifications, the yield increases that they recorded in field experiments conducted in three villages ranged from 12 to $19 \%$, which were not higher than the previously reported values. They also reported that the statistical analysis of the data on algalization experiments suggested that the effects of inoculation were inconsistent. Molecular characterisation of the occurrence of cyanobacteria from saline rice soils in Eastern Uttar Pradesh, India (Srivastava et al., 2009) showed that low salinity favoured the presence of heterocystous cyanobacteria, while very high salinity mainly supported non-heterocystous genera. Other reports on the distribution of cyanobacteria in rice fields of India (Choudhary \& Bimal, 2009; Selvi \& Sivakumar, 2012) and Bangladesh (Tahmida Begum et al., 2008) have confirmed the earlier report of Roger and Kulasooriya (1980), that in most rice fields $\mathrm{N}_{2}$ fixing cyanobacterial diversity is correlated to neutral to near neutral $\mathrm{pH}$ and available $\mathrm{P}$, and follows a successional pattern from an initial predominance of unicellular and non-heterocystous types to heterocystous potentially $\mathrm{N}_{2}$ fixing forms as the rice plants grow and reach maturity. These changes have been attributed to high light intensity and release of soil nitrogen during initial land preparations (priming effect), and the seedling stage of rice favouring the growth of unicellular and non-heterocystous cyanobacteria together with certain green algae. Later the growth of the rice plants absorbing soil nitrogen together with their light shading effects become favourable for the growth of heterocystous forms. It is therefore likely that the benefits of $\mathrm{N}_{2}$ fixation by cyanobacteria may be available to a successive crop rather than the standing crop unless a dominant population of diazotrophic species can be established early during the cultivation cycle. Kim and Lee (2006) have reported on the diversity of heterocystous cyanobacteria in rice fields of Korea. Examining 200 soil samples collected from 10 different sites, 142 isolates were obtained. Of these $90 \%$ belonged to the two genera: Nostoc and Anabaena. Testing the tolerance of these isolates to 10 fungicides used commonly in Korea, they found Nostoc to be more tolerant than Anabaena to fungicides and that benomyl had the highest acute toxicity on cyanobacteria.

The application of cyanobacterial biofertiliser technology in Sri Lanka was successful only up to the stage of pot experiments. Most of the cyanobacterial inoculants added to the rice fields could not overcome consumption by the rice field micro-fauna and competition by the indigenous micro-flora and failed to colonise the fields (Kulasooriya \& Hirimburegama, 1989). More recently it has been demonstrated that $\mathrm{N}_{2}$ fixing species of cyanobacteria could be incorporated with certain eubacteria and fungi to form biofilmbiofertilisers and preliminary field trials with such multimicrobial biofertilisers have given encouraging results with rice (Kulasooriya \& Seneviratne, 2012).

Quoting a number of publications Kulasooriya (2011) has reviewed the potential uses of cyanobacteria for wastewater treatment, as low cost converters of odour causing diary effluents, to remove heavy metals from textile, pharmaceutical and other industrial effluents, and cleaning up of oil spills sometimes in conjunction with sulphate reducing and other heterotrophic bacteria with which they form biofilms and are candidates for biofuel production.

Compared to free living cyanobacteria, the application of Azolla in rice cultivation has been more successful and is widely used particularly in Vietnam, China, Myanmar and certain parts of The Philippines. Azolla has been traditionally used as a green manure in rice cultivation in Vietnam and possibly other East Asian countries for centuries well before their nitrogen fixing ability was detected (Lumpkin \& Plucknett, 1982). The earliest records of Azolla have been found in a Chinese dictionary Er Ya written some 2000 years ago and a Chinese book on agricultural techniques written by Jin Si Xue in 540 A.D. mentions Azolla with respect to plant cultivation.

The status of this technology has been well reviewed at a workshop held in Fuzhou, China and published by the International Rice Research Institute (IRRI, 1987). Even in Sri Lanka this technology appeared to be more feasible than free living cyanobacterial fertilisers. In Sri Lanka Azolla grew well in rice fields at Ambalantota (low country Dry Zone), Bombuwela (low country Wet Zone) and Peradeniya (mid country Wet Zone) and showed a potential to replace an equivalent of 55 to $85 \mathrm{kgN} /$ ha of chemical $\mathrm{N}$ fertiliser (Kulasooriya et al., 1987). The major constraints for the adoption of Azolla technology by rice farmers are, handling of fresh bulky material, maintenance of fresh cultures during the dry (fallow) periods, the need for frequent $\mathrm{P}$ fertiliser applications and the susceptibility of Azolla to pests and pathogens particularly under tropical, humid, warm weather. It is therefore evident that the utilisation of $\mathrm{N}_{2}$ fixing cyanobacteria and their symbiotic systems as fertilisers for rice have only limited potential for widespread application. 
Azolla is also used to some extent as a nutritive fodder supplement in China, Myanmar, The Philippines, Thailand and Vietnam in poultry, piggery and cattle farming (Lumpkin \& Plucknett, 1982; IRRI, 1987).

A number of publications on Azolla have appeared since the 1980s including two extensive reviews (Wagner, 1997; Kannaiyan \& Kumar, 2005). Although these publications have not added much novel information, they reflect that the interest in the use of Azolla for rice cultivation as well as other applications such as production of nutritive animal food, biofuel and biogas have spread across the world. Carrapiço et al. (2000) have reported testing the potential of Azolla in Africa. Bocchi and Malgioglio (2010) have examined its use for rice cultivation in the Po Valley area of Italy in which resistance to herbicides and tolerance to low temperatures in winter were used to select strains suitable for field application. Montano (2012) has written a blog on its potential value for multiple uses in Ecuador. All these reports emphasise the value of Azolla as a low cost, environmentally benign biofertiliser for rice after conducting limited field trials in experimental plots. None of them present evidence of its extensive use by local farmers. A very comprehensive review has been published by Issa et al. (2014) and this report has an extensive coverage on all aspects of nitrogen fixation. It is the only article that mentions the application of Azolla in the Republic of China as a green manure in 3.2 million acres of rice cultivation, without reference to any specific publications. The current prospects on the widespread use of Azolla in rice cultivation appear to be rather limited. Unless Azolla is cultivated as a multi-purpose plant based upon rice production it is unlikely to be economically attractive even to resource poor farmers. An excellent presentation has been made by Liu (1987) where he has demonstrated a novel system of Azolla-Rice-Fish culture. According to his results it has significantly improved the economic gains per unit area of land as well as the ecological balance including the reduction of weed growth and control of aquatic fauna along with the larval stages of a number of insects, some of which are voracious pests of Azolla plants. It is therefore evident that a wide acceptance of Azolla can be ensured in countries which do not subsidise $\mathrm{N}$ fertilizers, in areas where water control is possible and if its use for rice production can be coupled with one or more other uses that can bring an additional income to the farmers.

The Azolla Foundation (theazollafoundation.org) has presented two very interesting aspects of this plant: its potential use for space travel and planetary colonisation and the '2004 Azolla Arctic Event'. In July 1980 a Vietnamese astronaut Phan Tuan has taken Azolla to the Soviet Salyut-6 Space Station for testing it as a candidate for Controlled Ecological Life Support Systems (CELSS) and a Chinese team has demonstrated that a16 $\mathrm{m}^{2}$ Azolla cultivation can provide $\mathrm{O}_{2}$ for two adults. In 2004 a reduced ice cover enabled the Arctic Coring Expedition drillship Vidar Viking to sail close to the North Pole and drill a scientific bore hole into the sediments of the Lomonosov Ridge beneath the ocean sea bed. The fossil specimens obtained appear morphologically identical to those of the present day Azolla plants. These 50 million year old sediments have formed during the Dinosaur Era when the world had a warmer climate with turtles and alligators living, and lush forests growing a few hundred miles off the North Pole. At that time the Arctic Ocean was a smaller land locked sea just like the present day Black Sea. The freshwater from the inland rivers and the ice melts is believed to have formed a plume over the seawater, which has enabled a massive growth of Azolla. When this biomass died and sank to the bottom it became too anoxic for microbial decomposition and the sediment became fossilised.

\section{CONCLUSION}

Originating as one of the earliest photo-autotrophic organisms of the primitive Earth, nitrogen fixing cyanobacteria have eventually established themselves as the only oxygenic photosynthetic prokaryotic group that could sustain the oxygen sensitive nitrogenase activity in them under aerobic conditions. A number of evolutionary trends appear to have been followed for this purpose as evident from the different adaptations shown by the present day species. Among these adaptations the development of the thick walled specialised cell, the heterocyst, appears to be widespread among filamentous species, while unicellular species exhibit a variety of adaptations, the exact mechanisms of some of which have yet to be elucidated. Similarly the enigmatic situation with the non-heterocystous, filamentous cyanobacterium Trichodesmium, which contributes significantly to the $\mathrm{N}$ budget of the oligotrophic deep oceans through its biological $\mathrm{N}_{2}$ fixation remains a challenge for future research.

Nitrogen fixation by free living cyanobacteria and their $\mathrm{N}_{2}$ fixing symbiotic associations make a significant contribution to the global natural nitrogen budget both in the marine and terrestrial ecosystems. Their ubiquitous global distribution including extreme habitats, which depicts their archaic ancestry, have enabled them to become frequent pioneers of natural colonisation. Their 
nitrogen fixation is perhaps crucial for the sustenance of certain vegetations in the Arctic, Antarctic, Tundra and Boreal forests. The only negative characteristic shown by certain species is the formation of toxigenic blooms in water bodies, but this should also be viewed as a natural defense mechanism, which provides them a survival advantage. Utilisation of these organisms and their symbiotic associations has the highest potential in rice cultivation, and with the other potential diverse uses cyanobacteria should be considered as an invaluable group of prokaryotic microorganisms that warrants care and conservation.

\section{REFERENCES}

1. Adams D.G., Duggan P.S. \& Owen J. (2012). Cyanobacterial symbioses. Ecology of Cyanobacteria II: Their Diversity in Space and Time (ed. B.A. Whitton), chapter 23, pp. 593 - 647. Springer, Dordrecht, New York and London. DOI: http://dx.doi.org/10.1007/978-94-007-3855-3_23

2. Aldea M.R., Kumar K. \& Golden J.W. (2008). Heterocyst development and pattern formation. Chemical Communication among Bacteria (eds. S.C. Winans \& B.L. Bassler), pp. 75 - 90. ASM Press, Washington DC, USA. DOI: http://dx.doi.org/10.1128/9781555815578.ch6

3. Aleksandra V., Drobac C., Dulic T.I., Stojanovic D.B. \& Svircer Z.B. (2007). The importance of extremophile cyanobacteria in the production of biologically active compounds. Proceedings of the National Academy of Sciences, Matica Srpksa Novi Sad, Serbia 112: 57 - 66.

4. Bandyopadhyay A., Elvitigala T., Liberton M. \& Pakrasi H.B. (2012). Variation in the rhythms of respiration and nitrogen fixation in members of the unicellular diazotrophic cyanobacterial genus Cyanothece. Plant Physiology 161: 1334 - 1346.

DOI: http://dx.doi.org/10.1104/pp.112.208231

5. Berman-Frank I., Lundgren P. \& Fallwoski P. (2003). Nitrogen fixation and photosynthetic oxygen evolution in cyanobacteria (mini review). Research in Microbiology 154: 157 - 164 .

6. Billi D., Baque M., Smith H. \& McKay C. (2013). Cyanobacteria from extreme deserts to space. Advances in Microbiology 3(6A): $80-86$.

DOI: http://dx.doi.org/10.4236/aim.2013.36A010

7. Bocchi S. \& Malgioglio A. (2010). Azolla-Anabaena as a biofertilizer for rice paddy fields in the Po Valley, a temperate rice area of northern Italy. International Journal of Agronomy 2010: 5.

DOI: http://dx.doi.org/10.1155/2010/152158

8. Bolhuis H., Severin I., Confurius-Guns V., Wollenzien U.I.A. \& Stal L.J. (2010). Horizontal transfer of the nitrogen fixation gene cluster in the cyanobacterium Microcoleus chthonoplastes. The ISME Journal 4: 121 - 130. DOI: http://dx.doi.org/10.1038/ismej.2009.99
9. Bothe H., Tripp J.H. \& Zer J.P. (2010a). Unicellular cyanobacteria with a new mode of life: the lack of photosynthetic oxygen evolution allows nitrogen fixation to proceed (mini review). Archives of Microbiology 192: $783-790$.

DOI: http://dx.doi.org/10.1007/s00203-010-0621-5

10. Bothe H., Schmitz O., Yates M.O. \& Newton W.E. (2010b). Nitrogen fixation and hydrogen metabolism in cyanobacteria. Microbiology and Molecular Biology Review 74(4): 529 - 551.

DOI: http://dx.doi.org/10.1128/MMBR.00033-10

11. Brauer V.S., Stomp M., Rosso C., van Beusekom S.A.M., Emmerich B., Stal L.J. \& Huisman J. (2013). Low temperature delays timing and enhances the cost of nitrogen fixation in the unicellular cyanobacterium Cyanothece. The ISME Journal 7: 2105 - 2115. DOI: http://dx.doi.org/10.1038/ismej.2013.103

12. Capone D.G., O’Neil J.M., Zer P. \& Carpenter E.J. (1990). Basis for diel variation in nitrogenase activity in the marine planktonic cyanobacterium Trichodesmium thiebautii. Applied Environmental Microbiology 56: 3532 - 3536.

13. Carpenter E.J. \& Romans K. (1991). Major role of the cyanobacterium Trichodesmium in nutrient cycling in the North Atlantic Ocean. Science 254: 1356 - 1358. DOI: http://dx.doi.org/10.1126/science.254.5036.1356

14. Carrapiço F. (2015). Can we understand evolution without symbiogenesis? Reticulate Evolution, Interdisciplinary Evolution Research (ed. N. Gontier), pp. 81 - 105. Springer International Publishing, Switzerland.

15. Carrapiço F., Teixeira G. \& Diniz M.A. (2000). Azolla as a biofertilizer in Africa: a challenge for the future. Revista de Ciencias Agrarias 23(3-4): 120 - 138.

16. Chen Y.B., Dominic B., Mellon M.T. \& Zehr J.P. (1998). Circadian rhythm of nitrogenase gene expression in the diazotrophic, filamentous non-heterocystous Trichodesmium sp. strain IMS101. Journal of Bacteriology 180: $3598-3605$.

17. Choudhary K.K. \& Bimal R. (2009). Distribution of nitrogen fixing cyanobacteria (Nostocaceae) during rice cultivation in fertilized and unfertilized paddy fields. Nordic Journal of Botany 28(1): 100 - 103.

DOI: http://dx.doi.org/10.1111/j.1756-1051.2009.00486.x

18. Cox R.M. (1966). Physiological studies on nitrogen fixation in the blue-green alga Anabaena cylindrica. Archives of Microbiology 53: 263 - 276. DOI: http://dx.doi.org/10.1007/bf00446673

19. Cumino A.C., Marcozzi C., Barreiro R. \& Salerno G.L. (2007). Carbon cycling in Anabaena sp. PCC 7120. sucrose synthesis in the heterocysts and possible role in nitrogen fixation. Plant Physiology 143: 1385 - 1397. DOI: http://dx.doi.org/10.1104/pp.106.091736

20. De P.K. (1939). The role of blue-green algae in nitrogen fixation in rice fields. Proceedings of the Royal Society B 127: $121-139$.

DOI: http://dx.doi.org/10.1098/rspb.1939.0014 
21. Dilworth M.J. (1966). Acetylene reduction by nitrogen fixing preparations from Clostridium pasteurianum. Biochimica Biophysica Acta 127: 285 - 294.

22. Drewes K. (1928). Uber die assimilation des luftstickstoffs durch blaualgen. Zentbl. Bakterial ParasitKde (Abt II) 76: $88-101$

23. Dudgale R.C., Menzel D.W. \& Ryther J.H. (1964). High nitrogen fixation rates in the Sargasso Sea and the Arabian Sea. Deep Sea Research 7: 298 - 300.

24. Fay P. \& Kulasooriya S.A. (1972). Tetrazolium reduction and nitrogenase activity in heterocystous blue-green algae. Archives of Microbiology 87: 341 - 352. DOI: http://dx.doi.org/10.1007/bf00409133

25. Fay P., Stewart W.D.P., Walsby A.E. \& Fogg G.E. (1968). Is the heterocyst the site of nitrogen fixation in blue-green algae? Nature 220: $810-812$.

DOI: http://dx.doi.org/10.1038/220810b0

26. Fay P. \& Walsby A.E. (1966). Metabolic activities of isolated heterocysts of the blue-green alga Anabaena cylindrica. Nature 209: $810-812$.

DOI: http://dx.doi.org/10.1038/209094a0

27. Finzi-Hart J.A., Pett-Ridge J., Weber P.K., Popa R., Fallon S.J., Gunderson T., Hutcheon I.D., Nealson K.H. \& Capone D.G. (2009). Fixation and fate of $\mathrm{C}$ and $\mathrm{N}$ in the cyanobacterium Trichodesmium using nanometerscale secondary ion mass spectrometry. Proceedings of the National Academy of Sciences 106(15): 6345 - 6350. DOI: http://dx.doi.org/10.1073/pnas.0810547106

28. Flores E., Herrero A.,Wolk C.P. \& Maldener I. (2006). Is the periplasm continuous in filamentous multicellular cyanobacteria? Trends in Microbiology 14: 439 - 443. DOI: http://dx.doi.org/10.1016/j.tim.2006.08.007

29. Fogg G.E. (1942). Studies on nitrogen fixation by bluegreen algae. I. nitrogen fixation by Anabaena cylindrica Lemn. Journal of Experimental Biology 19: 78 - 87.

30. Fogg G.E., Stewart W.D.P., Fay P. \& Walsby A.E. (1973). The Blue-Green Algae, pp. 459. Academic Press, London \& New York.

31. Forchhammer K. (2004). Global carbon/nitrogen control by $\mathrm{P}_{\mathrm{II}}$ signal transduction in cyanobacteria: from signals to targets. FEMS Microbiology Reviews 28: 319 - 333.

DOI: http://dx.doi.org/10.1016/j.femsre.2003.11.001

32. Foster R.A., Kuypers M.M.M., Vagner T., Paerl R.W., Musat N. \& Zehr J.P. (2011). Nitrogen fixation and transfer in open ocean diatom-cyanobacterial symbioses. The ISME Journal 5: $1484-1493$.

DOI: http://dx.doi.org/10.1038/ismej.2011.26

33. Francis K.O., de la Torre R. \& Cockell C.S. (2010). Isolation of novel extreme tolerant cyanobacteria from a rock dwelling microbial community by using exposure to low earth orbit. Applied Environmental Microbiology 76(7): $2115-2121$.

DOI: http://dx.doi.org/10.1128/AEM.02547-09

34. Frank B. (1889). Uber den experimentellen Nachweis der Assimilation freien Stickstoffs durch erbodenbewohnende Alge. Berlin Dt. botanik Ges. 7: 34 - 42.
35. Fredrickson C. \& Bergman B. (1995). Nitrogenase quantity varies diurnally in a subset of cells within colonies of the non-heterocystous cyanobacterium Trichodesmium sp. Microbiology 141: 2471 - 2478.

DOI: http://dx.doi.org/10.1099/13500872-141-10-2471

36. Fredrickson C. \& Bergman B. (1997). Ultrastructural characterization of cells specialised for nitrogen fixation in a non-heterocystous cyanobacterium Trichodesmium sp. Protoplasma 197: $76-86$.

DOI: http://dx.doi.org/10.1007/BF01279886

37. Gallon J.R. (1981). The oxygen sensitivity of nitrogenase: a problem for biochemists and microorganisms. Trends in Biochemical Sciences 6: $19-23$.

38. Gallon J.R. (1992). Reconciling the incompatible: $\mathrm{N}_{2}$ fixation and $\mathrm{O}_{2}$. New Phytologists 122: $571-609$. DOI: http://dx.doi.org/10.1111/j.1469-8137.1992.tb00087.x

39. Gallon J.R. \& Hamadi A.F. (1984). Studies on the effect of oxygen on acetylene reduction (nitrogen fixation) in Gloeotheca sp. ATCC 27152. Journal of General Microbiology 130: 495 - 503.

40. Gallon J.R., Hashem M.A. \& Chaplin A.E. (1991). Nitrogen fixation by Oscillatoria sp. under autotrophic and photoheterotrophic conditions. Journal of General Microbiology 137: 31 - 39.

DOI: http://dx.doi.org/10.1099/00221287-137-1-31

41. Herrero A., Muro-Pastor A.M., Valladares A. \& Flores E. (2004). Cellular differentiation and the NtcA transcription factor in filamentous cyanobacteria. FEMS Microbiology Reviews 28: 469 - 487.

DOI: http://dx.doi.org/10.1016/j.femsre.2004.04.003

42. Huang T.C. \& Chow W.M. (1991). Setting the circadian nitrogen fixing rhythm of the prokaryotic Synechococcus sp. RF1, while its nif gene is repressed. Plant Physiology 96: $324-326$.

DOI: http://dx.doi.org/10.1104/pp.96.1.324

43. International Rice Research Institute (IRRI) (1987). Azolla utilization. Proceedings of the Workshop on Azolla Use, Fuzhou, Fujian, China, 31 March - 5 April 1985, International Rice Research Institute, Los Banos, The Philippines, p. 296.

44. Issa A.A., Abd-Alla M.H. \& Ohyama T. (2014). Nitrogen fixing cyanobacteria: future prospect. Advances in Biology and Ecology of Nitrogen Fixation (ed. T. Ohyama), pp. 23. InTech, Rijeka, Croatia - European Union.

45. Janaki S. \& Wolk C.P. (1982). Synthesis of nitrogenase by isolated heterocysts. Biochimica Biophysica Acta 696: $187-192$.

46. Janson S., Carpenter E.J. \& Bergman B. (1994). Compartmentalization of nitrogenase in a nonheterocystous cyanobacterium: Trichodesmium contortum. FEMS Microbiology Letters 118: 9 - 14.

DOI: http://dx.doi.org/10.1111/j.1574-6968.1994.tb06796.x

47. Jones K. (1990). Aerobic nitrogen fixation by Lyngbya sp., a marine tropical cyanobacterium. British Phycological Journal 25: 287 - 289.

DOI: http://dx.doi.org/10.1080/00071619000650291 
48. Kannaiyan S. \& Kumar K. (2005). Azolla Biofertilizer for Sustainable Rice Production, pp. 425. Daya Publishing House, A Division of Astral International (Pvt.) Ltd., New Delhi, India.

49. Karl D., Letelier R., Tupas L., Dore J., Christian J. \& Hebel D. (1997). The role of nitrogen fixation in biogeochemical cycling in the sub-tropical North Pacific Ocean. Nature 388: 533 - 538.

DOI: http://dx.doi.org/10.1038/41474

50. Kenyon C.N., Rippka R. \& Stanier R.Y. (1972). Fatty acid composition and physiological properties of some filamentous blue-green algae. Archives of Microbiology 83: $216-236$. DOI: http://dx.doi.org/10.1007/bf00645123

51. Kim J.D. \& Lee G.G. (2006). Diversity of heterocystous filamentous cyanobacteria (blue-green algae) from rice fields and their differential susceptibility to ten fungicides used in Korea. Journal of Microbiology and Biotechnology 16(2): $240-246$.

52. Kneip C., Vo $\beta$ C., Lockhart P.J. \& Maier U.G. (2008). The cyanobacterial endosymbiont of the unicellular algae Rhopalodia gibba shows reductive genome evolution. BMC Evolutionary Biology 8: 30.

DOI: http://dx.doi.org/10.1186/1471-2148-8-30

53. Kulasooriya S.A. (2005). Potential toxin producing cyanobacteria (blue-green algae) in water resources of Sri Lanka. Workshop on Hygiene Promotion and Water Quality Surveillance for Water Board and Health Department Officials, Plant Genetic Resources Center, Gannoruwa, Sri Lanka.

54. Kulasooriya S.A. (2008). Biological Nitrogen Fixation: Fundamentals and Utilization. Peradeniya Science Publication No: 27, pp. 143. Science Education Unit, Faculty of Science, University of Peradeniya, Peradeniya.

55. Kulasooriya S.A. (2011). Cyanobacteria: pioneers of planet earth. Ceylon Journal of Science (Biological Science) 40(2): $71-88$.

56. Kulasooriya S.A. \& Hirimburegama W.K. (1989). Phototrophic nitrogen fixation in wetland rice. Biological Nitrogen Fixation Associated with Rice Production (eds. S.K. Dutta \& C. Sloger), pp. 191 - 210. Oxford/IBH Publishers, New Delhi, Bombay \& Calcutta, India.

57. Kulasooriya S.A., Hirimburegama W.K. \& Abeysekera S.W. (1987). Use of Azolla in Sri Lanka. Azolla Utilization, pp. 131 - 140. International Rice Research Institute, Los Banos, Laguna, The Philippines.

58. Kulasooriya S.A., Lang N.J. \& Fay P. (1972). The heterocysts of blue-green algae. III differentiation and nitrogenase activity. Proceedings of the Royal Society $B$ 181: $199-209$.

DOI: http://dx.doi.org/10.1098/rspb.1972.0046

59. Kulasooriya S.A., Roger P.A., Barraquio W.L. \& Watanabe I. (1981a). Epiphytic nitrogen fixation on weeds in a rice field ecosystem. Nitrogen Cycling in South-East Asian Wet Monsoonal Ecosystems (eds. R. Wetselaar, J.R. Simpson \& T. Rosswall), pp. $56-61$. Australian Academy of Sciences, Canberra, Australia.
60. Kulasooriya S.A., Roger P.A., Barraquio W.L. \& Watanabe I. (1981b). Epiphytic nitrogen fixation in deepwater rice. Soil Science and Plant Nutrition 27: 19 - 27.

DOI: http://dx.doi.org/10.1080/00380768.1981.10431251

61. Kulasooriya S.A. \& Seneviratne G. (2012). Transfer of microbial inoculant technology to rural farmers in Sri Lanka. International Symposium on Improving the Quality of Life Through Science, at the Inaugural General Assembly of the Association of Academies and Societies of Sciences in Asia, Galadari Hotel, Colombo, Sri Lanka, $16-19$ October, pp. $73-77$.

62. Kumar K., Mella-Herrera R.A. \& Golden J.W. (2009). Cyanobacterial heterocysts. Cold Spring Harbor Perspectives of Biology 2(4): a000315.

63. Lang N.J. \& Fay P. (1971). The heterocysts of blue-green algae. II details of ultrastructure. Proceedings of the Royal Society B 178: 193 - 202.

DOI: http://dx.doi.org/10.1098/rspb.1971.0061

64. Lin S., Henze S., Lundgren P., Bergman B. \& Carpenter E.J. (1998). Whole-cell immune localization in marine diazotrophic cyanobacteria, Trichodesmium spp. Applied Environmental Microbiology 64: 3052 - 3058.

65. Liu Chung-Chu (1987). Reevaluation of Azolla utilization in agricultural production. Azolla Utilization, pp. $67-76$. The International Rice Research Institute, Los Banos, Laguna, The Philippines.

66. Lumpkin T.A. \& Plucknett D.L. (1982). Azolla as a green manure: Use and Management in Crop Production, pp. 230. Westview Press, Boulder, Colorado, USA.

67. Maracarelli A.M., Baker M.A. \& Wourtsbaugh W.A. (2008). Is in-stream $\mathrm{N}_{2}$ fixation an important $\mathrm{N}$ source for benthic communities and stream ecosystems? Journal of the North American Benthological Society 27(1): $186-211$.

DOI: http://dx.doi.org/10.1899/07-027.1

68. Marcozzi C., Cumino A.C. \& Salerno G.L. (2009). Role of NtcA, a cyanobacterial global nitrogen regulator, in the regulation of sucrose metabolism gene expression in Anabaena sp. PCC 7120. Archives of Microbiology 191: $255-263$.

DOI: http://dx.doi.org/10.1007/s00203-008-0450-y

69. Mariscal V., Herrero A. \& Flores E. (2007). Continuous periplasm in a filamentous, heterocyst-forming cyanobacterium. Molecular Microbiology 65: 1139 - 1145. DOI: http://dx.doi.org/10.1111/j.1365-2958.2007.05856.x

70. Martin-Figueroa E., Navarro F. \& Florencio F.J. (2000). The GS-GOGAT pathway is not operative in the heterocysts cloning and expression of glsF gene from the cyanobacterium Anabaena sp. PCC 7120. FEBS Letters 476: 282 - 286.

71. Meeks J.C. \& Elhai J. (2002). Regulation of cellular differentiation in filamentous cyanobacteria in free-living and plant-associated symbiotic growth states. Microbiology and Molecular Biology Reviews 66: 94 - 121.

DOI: http://dx.doi.org/10.1128/MMBR.66.1.94-121.2002

72. Mishra U. \& Pabbi S. (2004). Cyanobacteria: a potential biofertilizer for rice. Resonance 9(6): $6-10$. DOI: http://dx.doi.org/10.1007/BF02839213 
73. Mitsui A., Kumazawa S., Takahashi A., Ikemoto H., Cao S. \& Arai T. (1986). Strategy by which nitrogen-fixing unicellular cyanobacteria grow photoautotrophically. Nature 323: 720 - 722.

DOI: http://dx.doi.org/10.1038/323720a0

74. Moal M.L. \& Beigala I. (2009). Diazotrophic unicellular cyanobacteria in the northwestern Meditarrenean Sea: a seasonal cycle. Limnology and Oceanography 54: $845-855$.

DOI: http://dx.doi.org/10.4319/1o.2009.54.3.0845

75. Moisander P.H., Beinart R.A., Hewson I., White A.E., Johnson K.S., Carlson C.A., Montoya J.P. \& Zehr J.P. (2010). Unicellular cyanobacterial distributions broaden the oceanic nitrogen fixation domain. Science 327: $1512-1514$.

DOI: http://dx.doi.org/10.1126/science. 1185468

76. Montano M. (2012). Azolla: a new paradigm of the future of rice. Development Marketplace Blog. The World Bank. Available at http://blogs.worldbank.org/dmblog/azolla-anew-paradigm-of-the-future-of-rice

77. Montoya J.P., Holl C.M., Zehr J.P., Hansen A., Villareal T.A. \& Capone D.G. (2004). High rates of nitrogen fixation by unicellular diazotrophs in the oligotrophic Pacific Ocean. Nature 430: 1027 - 1032. DOI: http://dx.doi.org/10.1038/nature02824

78. Mulholland M.R. \& Capone D.G. (2000). The nitrogen physiology of the marine nitrogen fixing cyanobacterium Trichodesmium spp. Trends in Plant Science 5: 148 - 153.

79. Murry M.A., Horne A.J. \& Bennemann J.R. (1984). Physiological studies of oxygen protective mechanisms in the heterocysts of Anabaena cylindrica. Applied Environmental Microbiology 47: 449 - 454.

80. Murry M.A. \& Wolk C.P. (1989). Evidence that the barrier to the penetration of oxygen into the heterocysts depends upon two layers of the envelope. Archives of Microbiology 151: $469-474$.

DOI: http://dx.doi.org/10.1007/BF00454860

81. Nadis S. (2003). The cells that rule the seas. Scientific American 289(6): 52 - 57.

DOI: http://dx.doi.org/10.1038/scientificamerican1203-52

82. Needoba J.A., Foster R.A., Sakamoto C., Zehr J.P. \& Johnson K.S. (2007). Nitrogen fixation by unicellular diazotrophic cyanobacteria in the temperate oligotrophic North Pacific Ocean. Limnology and Oceanography 52: $1317-1327$.

DOI: http://dx.doi.org/10.4319/1o.2007.52.4.1317

83. Ortega-Calvo J.J. \& Stal L.J. (1991). Diazotrophic growth of the unicellular cyanobacterium Gloeotheca sp. PCC 6909 in continuous culture. Journal of General Microbiology 137: 1789 - 1797.

DOI: http://dx.doi.org/10.1099/00221287-137-8-1789

84. Pearson H.W., Marlin G. \& Howsley R. (1981). Physiological studies on in vivo nitrogenase activity by axenic cultures of the blue-green alga Microcoleus chthnoplastes. British Phycological Journal 16: 139.
85. Pratt B.S. \& Thiel T. (2014). Regulation of nitrogenase gene expression by transcript stability in the cyanobacterium Anabaena variabilis. Journal of Bacteriology 196(20): $3609-3621$.

DOI: http://dx.doi.org/10.1128/JB.02045-14

86. Prechtl J., Kneip C., Lockhart P., Wenderoth K. \& Maier U.G. (2004). Intracellular spheroid bodies of Rhopalodia gibba have nitrogen-fixing apparatus of cyanobacterial origin. Molecular Biology and Evolution 21: 1477 - 1481. DOI: http://dx.doi.org/10.1093/molbev/msh086

87. Quesada A. \& Fernandez-Valiente E. (1996). Relationship between abundance of $\mathrm{N}_{2}$ fixing cyanobacteria and environmental features of Spanish rice fields. Microbial Ecology 32(1): 59 - 71.

DOI: http://dx.doi.org/10.1007/BF00170107

88. Ramamurthy V.D. \& Krishnamurthy S. (1968). Nitrogen fixation by the blue-green alga Trichodesmium erythraenum (Ehr.). Current Science 37: 21 - 22.

89. Reddy K.J., Haskell J.B., Sherman D.M. \& Sherman L.A. (1993). Unicellular aerobic nitrogen fixing cyanobacteria of the genus Cyanothece. Journal of Bacteriology 175(5): $1284-1292$.

90. Rippka R., Neilson A., Kunisawa R. \& Cohen-Bazire G. (1971). Nitrogen fixation by unicellular blue-green algae. Archives of Microbiology 76: 341 - 348.

DOI: http://dx.doi.org/10.1007/bf00408530

91. Roger P.A. \& Kulasooriya S.A. (1980). Blue- Green Algae and Rice, p. 113. International Rice Research Institute, Los Banos, Laguna, The Philippines.

92. Roger P.A., Kulasooriya S.A., Barraquio W.L. \& Watanabe I. (1981). Epiphytic nitrogen fixation on lowland rice plants. Nitrogen Cycling in South-East Asian Wet Monsoonal Ecosystems (eds. R. Wetselaar, J.R. Simpson \& T. Rosswall), pp. 62 - 66. Australian Academy of Sciences, Canberra, Australia.

93. Roger P.A., Santiago-Ardales S., Reddy P.M. \& Watanabe I. (1987). The abundance of heterocystous blue-green algae in rice soils and inocula used for application in rice fields. Biology and Fertility of Soils 5(2): $98-105$.

DOI: http://dx.doi.org/10.1007/BF00257642

94. Sandh G., Xu L. \& Bergman B. (2012). Diazocyte development in the marine diazotrophic cyanobacterium Trichodesmium Microbiology 158: 345 - 352.

DOI: http://dx.doi.org/10.1099/mic.0.051268-0

95. Schloesing T. \& Laurent E. (1892). Sur la fixationde l'azote libre par les plantes. Annals of the Institute of Pasteur, Paris 6: 824 - 840 .

96. Schollhorn R. \& Burris R.H. (1966). Study of intermediates in nitrogen fixation. Proceedings of the Federation of American Society of Experimental Biology 25: 710.

97. Seckbach J. (ed) (2002). Symbiosis: Mechanisms and Model Systems. Kluwer Academic, Dordrecht, The Netherlands. DOI: http://dx.doi.org/10.1007/0-306-48173-1

98. Selvi K.T. \& Sivakumar K. (2012). Distribution of heterocystous cyanobacteria in rice fields of Cuddalore 
District, Tamil Nadu. International Journal of Life Sciences and Pharmaceutical Research 2(4): 30 - 39.

99. Shapiro J.A. (2012). Cell merges and the evolution of new life forms: symbiogenesis rather than selection. The Huffpost Science Blog. Available at http://www. huffingtonpost.com/james-a-shapiro/cell-mergersevolution-life b 1807742.html

100. Singh R.N. (1961). Role of Nitrogen Fixing Blue-Green Algae in Nitrogen Economy of Indian Agriculture, p. 175. Indian Council for Agricultural Research, New Delhi, India.

101. Srivastava A.K., Bhargawa P., Kumar A., Rai L.C. \& Neilan B.A. (2009). Molecular characterization and effect of salinity on cyanobacterial diversity in rice fields of Eastern Uttar Pradesh, India. Saline Systems 5: 4. DOI: http://dx.doi.org/10.1186/1746-1448-5-4

102. Staal M., Meysman F.J.R. \& Stal J. (2003). Temperature excludes $\mathrm{N}_{2}$ fixing heterocystous cyanobacteria in the tropical oceans. Nature 425: $504-507$.

DOI: http://dx.doi.org/10.1038/nature01999

103. Stancheva R., Sheath R.G., Read B.A., McArhtur K.D., Schroepfer C., Kociolek J.P. \& Fetscher A.E. (2013). Nitrogen-fixing cyanobacteria (free-living and diatom endosymbionts): their use in southern California stream bioassessment. Hydrobiologia 720: 111 - 127.

DOI: http://dx.doi.org/10.1007/s10750-013-1630-6

104. Steunou A.S., Bhaya D., Bateson M.M., Melendrez M.C., Ward D.M., Brecht E., Peters J.W., Kuhl M. \& Grossman A.R. (2006). In situ analysis of nitrogen fixation and metabolic switching in unicellular thermophilic cyanobacteria inhabiting hot spring microbial mats. Proceedings of the National Academy of Science (USA) 103(7): 2398 - 2403.

DOI: http://dx.doi.org/10.1073/pnas.0507513103

105. Stewart W.D.P. \& Lex M. (1970). Nitrogenase activity in Plectonema boryanum strain 594. Archives of Microbiology 73: $250-260$.

106. Tahmida Begum Z.N., Mandal R. \& Farzana B.A. (2008). Quantification and nitrogen fixation of cyanobacteria in rice field soils of Bangladesh. Bangladesh Journal of Botany 37(2): 183 - 188.

107. The Azolla Foundation. theazollafoundation.org

108. Thomas J. (1970). Absence of pigments of photosystem II of photosynthesis in heterocysts of a blue-green alga. Nature 228: 181 - 183.

DOI: http://dx.doi.org/10.1038/228181b0

109. Thompson A.W., Foster R.A., Krupke A., Carter B.J., Musat N., Vaulot D., Kuypers M.M.M. \& Zehr J.P. (2012). Unicellular cyanobacterium symbiotic with a single celled eukaryotic alga. Science 337: 1546 - 1550. DOI: http://dx.doi.org/10.1126/science. 1222700

110. Thompson A.W. \& Zehr J.P. (2013). Cellular interactions: lessons from the nitrogen fixing cyanobacteria-(mini review). Journal of Phycology 49: 1024 - 1035. DOI: http://dx.doi.org/10.1111/jpy.12117
111. Tripp J.H., Bench S.R., Turk K.A., Foster R.A., Desany B.A., Niazi F., Affourtit J.P. \& Zehr J.P. (2010). Metabolic streamlining in an open-ocean nitrogen fixing cyanobacterium. Nature 464: 90 - 94.

DOI: http://dx.doi.org/10.1038/nature08786

112. Venkataraman G.S. (1972). Algal Biofertilizers and Rice Cultivation, p. 81. Today and Tomorrows Printers and Publishers, Calcutta, India.

113. Wagner G.M. (1997). Azolla: a review of its biology and utilization. The Botanical Reviews 63(1): $1-21$. DOI: http://dx.doi.org/10.1007/BF02857915

114. Wanigatunge R.P. (2014). Identification and characterization of cyanobacteria in different climatic zones of Sri Lanka using 16S rRNA genes and detection of toxin producing cyanobacterial species using molecular markers. PhD thesis. University of Colombo, Colombo, Sri Lanka.

115. Watanabe I., Ventura W., Cholitkul W., Roger P.A. \& Kulasooriya S.A. (1981). Potential of biological nitrogen fixation in deepwater rice. Proceedings of the Deepwater Rice Workshop, The International Rice Research Institute, Los Banos, Laguna, The Philippines, pp. $191-200$.

116. Wolk C.P. (1970). Aspects of the development of a bluegreen alga. Annals of the New York Academy of Sciences 175: $641-647$. DOI: http://dx.doi.org/10.1111/j.1749-6632.1970.tb45181.x

117. Wolk C.P. (1982). Heterocysts. The Biology of Cyanobacteria (eds. N.G. Carr \& B.A. Whitton), pp. 359 - 386. University of California Press, Berkeley, California, USA.

118. Wolk C.P., Austin S.M., Bortins J. \& Galonsky A. (1974). Autoradiographic localization of ${ }^{13} \mathrm{~N}$ after fixation of ${ }^{13} \mathrm{~N}$ labelled nitrogen gas by a heterocyst-forming blue green alga. Journal of Cell Biology 61: 440 - 453.

DOI: http://dx.doi.org/10.1083/jcb.61.2.440

119. Wolk C.P. \& Wojciuch C. (1971). Photo reduction of acetylene by heterocysts. Planta 97: $126-134$.

DOI: http://dx.doi.org/10.1007/BF00386760

120. Wood E.F.J. (1965). Marine Microbial Ecology, p. 243. Chapman Hall, London, UK.

121. Wyatt J.T. \& Silvey J.K.G. (1969). Nitrogen fixation by Gleoecapsa. Science 165: 908 - 909. DOI: http://dx.doi.org/10.1126/science.165.3896.908

122. Wyman M., Zehr J.P. \& Capone D.G. (1996). Temporal variability in nitrogenase gene expression in a natural population of the marine cyanobacterium Trichodesmium theibautii. Applied Environmental Microbiology 62: $1073-1075$.

123. Zehr J.P., Wyman M., Miller V., Duguay I. \& Capone D.G. (1993). Modification of the Fe-protein of nitrogenase in natural populations of Trichodesmium thiebautii. Applied Environmental Microbiology 59: 669 - 676.

124. Zhang C.C., Laurent S., Sakr S., Peng L. \& Be'du S. (2006). Heterocyst differentiation and pattern formation in cyanobacteria: a chorus of signals. Molecular Microbiology 59: $367-375$.

DOI: http://dx.doi.org/10.1111/j.1365-2958.2005.04979.x 
125. Zhang L.C., Chen Y.F., Chen W.L. \& Zhang C.C. (2008). Existence of periplasmic barriers preventing green fluorescent protein diffusion from cell to cell in the cyanobacterium Anabaena sp. strain PCC 7120. Molecular Microbiology 70: 814 - 823 .
126. Zhao J. \& Wolk C.P. (2008). Developmental biology of heterocysts, 2006. Myxobacteria: Multicellularity and Differentiation (ed. D.E. Whitworth), pp. $397-418$. ASM Press, Washington DC, USA.

DOI: http://dx.doi.org/10.1128/9781555815677.ch23 